\title{
PERANCANGAN DESAIN KEMASAN DAN BRAND PUTU PIRING BU KAY
}

PACKAGING DESIGN AND BU KAY PUTU BRAND DESIGN

\author{
Satriadi $^{1)}$, Sudirman ${ }^{2 *}$, Siti Mardiyah ${ }^{3)}$, Hari Purwanto ${ }^{4)}$, Aulia Ageng Ichtiarni ${ }^{5)}$, \\ Fiqih Fitrianti ${ }^{6}$ \\ ${ }^{1)}$ Manajemen, STIE Pembangunan Tanjungpinang, Kota Tanjungpinang, \\ Provinsi Kepulauan Riau. email: satriadi456@gmail.com \\ ${ }^{2)}$ Manajemen, STIE Pembangunan Tanjungpinang, Kota Tanjungpinang, \\ Provinsi Kepulauan Riau. email: dhiman200725@gmail.com \\ ${ }^{3)}$ Manajemen, STIE Pembangunan Tanjungpinang, Kota Tanjungpinang, \\ Provinsi Kepulauan Riau. email: sitimardiah444@gmail.com \\ ${ }^{4)}$ Manajemen, STIE Pembangunan Tanjungpinang, Kota Tanjungpinang, \\ Provinsi Kepulauan Riau. email: harrypurwanto65@gmail.com \\ ${ }^{5)}$ Manajemen, STIE Pembangunan Tanjungpinang, Kota Tanjungpinang, \\ Provinsi Kepulauan Riau. email: auliaagengichtiarni060@gmail.com \\ ${ }^{6)}$ Akuntansi, STIE Pembangunan Tanjungpinang, Kota Tanjungpinang, \\ Provinsi Kepulauan Riau. email: fiqihfitrianti00@gmail.com
}

\begin{abstract}
ABSTRAK
Kue putu piring $\mathrm{Bu}$ Kay merupakan produsen pembuat kue tradisonal khas melayu di Kelurahan Dompak tepatnya ditempat pariwisata Kota Tanjungpinang yakni Tanjung Setumu sejak tahun 2010. Produk-produk yang dijual oleh Bu Kay adalah putu piring, putu mayang, donat melayu (Domel), kue kacang selimut dan roti kirai. Perancangan ini menjawab berbagai permasalahan yang ditemukan dalam kemasan $\mathrm{Bu}$ Kay, yang kurang sesuai dengan positioning Bu Kay, yang enak, higienis dan berkualitas. Oleh karena itu, dalam perancangan ini akan dibuat sebuah kemasan yang praktis baik untuk dibawa untuk oleh-oleh dengan ciri khas Kelurahan Dompak.Perancangan ini menggunakan metode penelitan wawancara, dokumentasi,studi kepustakaan dan internet.Metode analisis menggunakan SWOT dan View.
\end{abstract}

Kata kunci: Desain Kemasan, Merek, Kue Putu Piring

\section{ABSTRACT}

Bu Kay's putu plate is a traditional Malay cake maker in Dompak Village, precisely at the Tanjungpinang City tourism place, namely Tanjung Setumu since 2010. The products sold by Bu Kay are putu dishes, putu mayang, Malay donuts (Domel), and peanut cakes.blankets and bread rolls.This design addresses various problems found in Bu Kay's packaging, which is not in line with Bu Kay's positioning, which is delicious, hygienic and of good quality.Therefore, in this design a practical package will be made which is good to carry for souvenirs with the characteristics of Dompak Village.This design uses research methods of interviews, documentation, literature study and the internet.The analysis method uses SWOT and View.

Keywords: Packaging Design, Brand, Cake Putu Plate

\section{PENDAHULUAN}

Perkembangan usaha yang semakin pesat, mengakibatkan persaingan yang cukup ketat antar perusahaan.Salah satu bidang usaha yang saat ini mulai berkembang adalah produk makanan yaitu kue tradisonal.Sudah banyak perusahaan yang memproduksi kue cukup besar di Indonesia.

Saat ini, pasar kue di Indonesia memiliki potensi yang besar bagi para pelaku bisnis, karena walaupun kue bukan makanan
pokok.Akan tetapi seiring berjalannya waktu, terjadi berbagai perkembangan jenis-jenis makanan.Seperti munculnya makanan ringan yang sebenarnya bukan termasuk ke dalam kebutuhan pokok manusia, tetapi mulai menjadi konsumsi sehari-hari masyarakat.Pada era sekarang ini, makanan ringan juga telah mengalami perkembangan fungsi. Tidak hanya menjadi konsumsi sehari-hari atau penunda rasa lapar, akan tetapi juga bisa digunakan menjadi oleh-oleh. 
Oleh karena itu dalam bidang ekonomi inovasi potensi lokal yang hendak diberdayakan adalah produk Usaha Mikro, Kecil dan Menengah (UMKM) bersama mahasiswa KKN, Yayasan Kesejahteraan Madani (Yakesma) serta masyarakat sekitar lokasi (Kelurahan Dompak) KKN. Hal tersebut sesuai dengan prinsip KKN Covid 2020 yaitu pemberdayaan masyarakat yang dijadikan lokasi KKN.

Kelurahan Dompak juga merupakan salah satu Kelurahan yang memiliki destinasi wisata alam berupa pantai Tanjung Setumu yang tak kalah indah dari pantai Trikora dan Lagoi bay yang dimiliki Pemerintah Kabupaten Bintan. Dengan adanya pantai Tanjung Setumu masyarakat banyak memanfaatkan pantai tersebut sebagai upaya untuk mendapatkan penghasilan tambahan. Banyak dari warga setempat yang membuka usaha rumahan baik dari segi kuliner berupa rumah makan, kerupuk udang, kerupuk gonggong, keripik Ubi, aneka kue tradisonal lainnya serta membuat kerajinan seni rupa berupa cendramata dan juga souvenir yang dapat dijadikan oleh-oleh apabila wisatawan berkunjung ke pantai tanjung setumu.

Namun di tengah persaingan yang ketat tersebut, ada produsen yang memiliki prinsip untuk mempertahankan kualitas produknya.Produsen tersebut adalah Kue putu piring Bu Kay.Kue putu piring Bu Kay berdiri sejak tahun 2010 dengan produk awal putu piring dan donat melayu.Seiring berjalannya waktu, produsen mengembangkan usahanya dengan memproduksi beberapa jajanan tradisional lain yaitu putu mayang, kue kacang selimut dan roti kirai.

Produk-produk $\mathrm{Bu}$ Kay dijamin tidak menggunakan bahan pengawet dan menggunakan bahan-bahan alami yang berkualitas.Sayangnya walaupun produknya laris dan berkualitas, Kue putu piring Bu Kay masih belum memiliki kemasan dan logo yang cocok untuk membungkus produknya.Padahal, produsen mengungkapkan bahwa biasanya konsumen seringkali membeli untuk dijadikan oleholeh, untuk dibawa pulang ke rumah, untuk dinikmati di perjalanan, serta pesanan antar untuk dinikmati bersama keluarga.

Kue putu piring memiliki ukuran kemasan yang belum seragam.Sedangkan untuk bahan dasar kemasannya sendiri yaitu berbahan dasar plastik mika dan plastik untuk membungkus es.Berikut Gambar kemasan Kue Putu Piring Bu Kay masih menggunakan mika dan plastik pembungkus es.

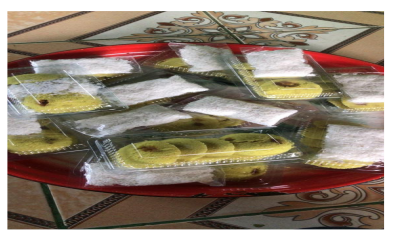

Gambar.1 Kue putu piring Bu Kay masih menggunakan pembungkus mika dan pembungkus plastik es untuk kelapanya

Adapun untuk UMKM putu piring sendiri permasalahan yang dihadapi ialah masih menggunakan peralatan tradisional dalam proses pembuatannya sehingga produk yang dihasilkan setiap harinya menjadi terbatas, kue putu piring juga memiliki hambatan lain dari segi pemasaran dan pengemasan karena dua kendala ini merupakan sesuatu hal yang saling berhubungan. Apabila kemasan tidak menarik maka untuk pemasarannya pun bakal mengalami hambatan dan bahkan dapat terhenti jika permasalahan tersebut tidak diatasi sesegera mungkin.

Solusi Permasalahan pertama yang ingin kami bantu adalah pemberian merek (branding) dan memperbaharui kemasan (packaging) usaha putu piring ibu kay. UMKM Putu Piring ini belum memiliki merek produk yang membuat produk ini mengalami kesulitan untuk dapat dikenal orang calon konsumen yang berada diluar Pulau Dompak itu sendiri dan masih sangat sederhananya kemasan yang digunakan sehingga tidak memiliki daya tarik tersendiri untuk produk putu piring tersebut.

Tujuan dari kegiatan pengabdian ini, ingin membantu membuat merek atau brand dan memberikan kemasan yang baru agar produk putu piring tersebut bisa memiliki nilai jual yang lebih dimata calon konsumen.

\section{Kemasan}

Menurut Julianti [1] kemasan merupakan tempat atau wadah untuk meningkatkan nilai dan fungsi sebuah produk. Menurut Kaihatu [2]Kata kemasan itu sendiri mengacu pada objek fisik itu sendiri. Material kemasan bisa 
berupa kertas, plastik, kaca, tekstil, logam, dan sebagainya. Menurut Shimp dan Andrews [3] desain kemasan bergantung pada penggunaan simbolisme untuk mendukung citra merek, dan membawa informasi yang diharapkan konsumen.

Menurut Powell[4]kemasan selain memiliki visual yang menarik juga harus memiliki banyak fungsi yaitu sebagai pengaman untuk melindungi produk terhadap berbagai kemungkinan yang dapat menjadi penyebab timbul kerusakan pada produk, kemudian harus ergonomic agar kemasan mudah dibawa atau dipegang, dibuka dan muda diambil atau dihabiskan isinya, mudah didistribusikan dari pabrik ke distributor dan sampai ke tangan konsumen dengan baik, memiliki identitas produk agar lebih mudah dikenali dan dibedakan dengan produk lainnya, kemasan yang ekonomis dan juga kemasan. Didalam desain kemasan harus ada petunjuk dalam kemasan yang dimanfaatkan untuk tujuan tersebut, seperti warna, desain, bentuk, nama merek, material fisik, serta label informasi produk.

Menurut Harminingtyas [5], kemasan adalah ujung tombak pemasaran bukan sekedar bungkus, tetapi untuk menentukan dan mengkomunikasikan positioning dan diferensiasi produk serta mampu menciptakan impulse buying.

Faktor-faktor desain kemasan Menurut Kaihatu [6], faktor-faktor yang harus ada untuk menjalankan fungsi kemasan adalah :

1. Faktor Pengaman:Kemasan harus memenuhi syarat keamanan dan kemanfaatan. Kemasan dapat melindungi produk dalam perjalanan pengiriman.

2. Faktor Ekonomi: kemasan merupakan suatu cara meningkatkan laba perusahaan. Oleh karena itu, kemasan harus dibuat seunik dan semenarik mungkin untuk memikat pelanggan.

3. Faktor Pendistribusian: kemasan harus mudah didistribusikan kemana saja sampai ke tingkat konsumen.

4. Faktor Informasi dan komunikasi: kemasan dapat mencerminkan produk dan citra merek. Oleh karena itu, kemasan harus mudah dilihat, dipahami, dan diingat. Melalui kemasan, identifikasi produk menjadi lebih efektif dan secara otomatis menjadi pembeda dengan produk pesaing.
5. Faktor Ergonomi: kemasan harus mudah dibawa, dipegang, dibuka, dan mudah diambil. Hal ini akan mempengaruhi kenyamanan pemakai produk atau konsumen.

6. Faktor Estetika: kemasan harus memiliki bentuk unik dan menarik, sehingga menjadi pembeda di tengah persaingan merek. Penggunaan warna, bentuk, merek/logo, ilustrasi, huruf, dan tata letak dapat dipergunakan untuk mencapai mutu daya tarik visual secara optimal.

7. Faktor Identitas: kemasan dapat menjadi ciri khas produk karena memiliki perbedaan dengan pesaing. Identitas yang akan membedakan kemasan yang satu dengan yang lain. Hal ini penting karena sebagai representasi visual meliputi: nama dan merek produk, logo, warna, desain, dan elemen lainnya.

\section{Merek/Brand Image}

Menurut Rieuwpassa [7] Brand adalahbagian dari salah satu unsur yang paling esensial untuk menciptakan image dalam suatu usaha. Branding sendiri merupakan halterpenting yang harus diperhatikan karena brand adalah identitas suatu usaha yang dapat membedakan dari usaha yang lainnya serta image atau citra usaha yang akan dikenal masyarakat.

Menurut Tjiptono [8] Merekdapat mempengaruhipersepsipelanggan

terhadapproduk yang akandibeli maka persaingan antarperusahaan adalah persainganpersepsi bukanhanya saja produk. Menurut Adams [9]"Terms such as identity, symbol, mark, word mark, and identity system have different meanings, depending on whom you talk to." Jadi Merek dengan adanya simbol, tanda, dan identitas lainnya mempunyai makna yang berbeda tergantung tujuan arah komunikasi. Berikut ini beberapa hal yang dapat dilakukan oleh merek atau $\log 0$ :

1) Membedakan dengan kompetitor.

2) Memfokuskan secara internal.

3) Memberikan identitas yang jelas.

4) Memungkinkan untuk membentuk hubungan secara dekat dengan konsumen.

5) Menciptakan peluang baru.

Konsumen yang memiliki citra yang positif terhadap suatu merek, akan lebih memungkinkan untuk melakukan pembelian. 
Merek dapat dideskripsikan dengan karakteristik-karakteristik tertentu seperti manusia, semakin positif deskripsi tersebut semakin kuat citra merek dan semakin banyak kesempatan bagi pertumbuhan merek itu.

Menurut Aline Wheeler brand memiliki tiga fungsi utama yaitu:

1) Navigation Brand yakni membantu konsumen memilih dari berbagai macam pilihan brand yang tersedia di pasaran.

2) Reassurance Brand yakni mengkomunikasikan kulitas yang tidak nampak dari sebuah produk atau jasa dan memastikan konsumen membuat pilihan yang tepat.

3) Engagement Brand menggunakan penggambaran, Bahasa, dan pendekatan untuk menarik konsumen agar dapat mengidentifikasi brand tersebut.

Dengan ini dapat dikatakan bahwa citra merek merupakan totalitas terhadap suatu merek yang terbentuk dalam persepsi konsumen.Citra pada suatu merek merefleksikan image dari perspektif konsumen dan melihat janji yang dibuat merek tersebut pada konsumennya.Citra merek terdiri atas asosiasi konsumen pada kelebihan produk dan karakteristik personal yang dilihat oleh konsumen pada merek tersebut.

Menurut Klimchuk Kemasan dapat juga sebagai salah satu brand image/citra merek.Kemasan juga dapat menjadi media untuk positioning citra merek kepada konsumen sehingga konsumen mudah mengingat dan fanatik untuk memilih produk.

Berdasarkan teori menurut para ahli diatas banyak sekali upaya-upaya yang pernah dilakukan oleh pihak Kelurahan Dompak dan Dinas Perdagangan dan Perindustrian Kota Tanjungpinang untuk mengembangkan dan memajukan UMKM yakni dengan memberikan pelatihan dan pembekalan kepada pelaku usaha, namun belum semuanya diterapkan oleh pelaku usahanya sendiri dengan kata lain dapat pembekalan namun tidak dijalankan. Oleh karena itu selaku Mahasiswa yang melakukan KKN di Kelurahan Dompak dengan bentuk dan tujuan dari Tri Dharma sebagai pengabdian kepada Masyarakat. Adapun tujuan pengabdian bagi Masyarakat sebagai berikut :

1. Sebagai sarana membangun jaringan kerjasama dengan pihak akademisi dan institusi.

2. Sebagai wadah, sarana atau forum yang dapat mendukung pelaksanaan dan peningkatan pemberdayaan ekonomi masyarakat di dompak khususnya di bidang ekonomi mikro, sehingga memiliki jiwa wirausaha yang memadai dari seluruh masyarakatnya.

\section{METODE PELAKSANAAN KEGIATAN Metode Perancangan}

Metode yang digunakan dalam perancangan ini adalah sebagai berikut :

1. Data Primer

a. Wawancara

Melakukan wawancara langsung dengan owner atau pemilik Bu Kayati atau dipanggil sapaan akrab oleh warga sekitar Tanjung Setumu dengan nama Bu Kay. Di antara lain untuk mengetahui lebih detail tentang produk, kemasan produk, termasuk kendala pengemasan produk.

b. Dokumentasi

Metode dokumentasi, yaitu dengan mengambil foto untuk melengkapi data-data yang sudah ada sebelumnya.Foto-foto yang telah diambil adalah foto produk beserta kemasannya.

2. Data Sekunder

a. Studi Pustaka

Data-data mengenai teori kemasan, fungsi dan kegunaan kemasan, perancangan kemasan dengan elemen-elemen visual yang menarik yang didapat melalui data digital, media cetak, dan lain-lain.

b. Internet

Data tentang bagaimana perkembangan cara pengemasan untuk makanan yang praktis dan menarik, juga untuk memantau data kompetitor.

\section{Instrumen/ Alat Pengumpulan Data}

Alat bantu yang dipilih dan digunakan dalam proses pengumpulan data adalah daftar wawancara, laptop, kamera, internet, smartphone, kertas dan alat tulis.

\section{Metode Analisis Data}

Metode yang digunakan untuk menganalisis data yang sudah diperoleh adalah dengan pendekatan kualitatif, dimana 
seluruh data akan dianalisis terlebih dahulu sehingga dapat menghasilkan kesimpulan bagaimana desain kemasan yang sebaiknya dibuat. Metode analisis digunakan sebagai cara untuk memahami subjek dan objek perancangan dengan lebih mendalam.

Metode analisis SWOT digunakan untuk mengetahui kekuatan, kelemahan, kesempatan, dan ancaman yang terjadi.SW (Strength and Weakness) adalah faktor internal, sedangkan OT (Opportunities and Threat) adalah faktor eksternal. Kedua faktor (internal dan eksternal) ini kemudian akan dibandingkan untuk menemukan bahan pertimbangan dalam menentukan tujuan dan strategi pemasaran dan komunikasi melalui kemasan tersebut. Dengan analisis SWOT, diketahui kekuatan produk, sehingga dapat dioptimalkan, apa kelemahan produk sehingga dapat diperbaiki, kesempatan atau peluang yang dapat dimanfaatkan, dan ancaman produk, sehingga dapat diantisipasi. Melalui analisis SWOT juga dapat dicari perbandingan antara produk dengan kompetitornya. Selain itu dalam perancangan ini akan menggunakan metode VIEW untuk menganalisa fitur kemasan. Hasil dari perbandingan ini nantinya akan dipakai sebagai bahan pertimbangan dalam melakukan proses re-desain.

Metode VIEW (Visibility, Information, Emotional Appeal, Workability).

1) Visibility

Jika disandingkan dengan produk lainnya, kemasan kue putu Bu Kay tidak sesuai dengan sifat produk karena menggunakan bahan plastik biasa.Kemasan ini juga kurang menarik perhatian konsumen.

- Warna, plastik mika yang digunakan tidak memiliki warna atau transparan.

- Logo, pada kemasan ini logo atau merek juga belum ada.

- Layout desain, belum ada layout yang pasti dalam kemasan ini.

\section{2) Information}

Informasi yang terdapat pada kemasan Kue putu Bu Kay adalah logo, foto produk, foto pemilik (Bu Kay) hanya polos saja.

\section{3) Emotional Appeal}

Kemasan kue Putu Bu Kay tidak memberikan suatu daya tarik emosional, seperti berkualitas, higienis, dan lainlain.Sehingga konsumen tidak tertarik pada kemasan tersebut.Kemasan ini juga tidak dapat menunjukkan kepada konsumen bahwa $\mathrm{Bu}$ Kay merupakan produk yang bisa dipercaya, terutama dari sisi higienis dan berkualitasnya.

4) Workability

Kemampuan dalam melindungi, menyimpan, serta menggunakan produk dengan baik harus bisa ditampilkan dalam kemasan.Kemasan dinilai dapat melindungi makanan di dalamnya. Akan tetapi, kemasan kue putu piring $\mathrm{Bu}$ Kay menggunakan plastik mika bening, sehingga tidak sesuai dengan sifat produk dan tidak dapat menjalankan fungsinya dalam segi penggunaan produk di dalamnya dengan baik.

\section{Analisis SWOT Kue Putu Piring Bu Kay}

a) Strength:

$>$ Produk sudah dikenal oleh masyarakat sekitar Kelurahan Dompak sejak lama sebagai produk berkualitas dengan khas kue melayu.

$>$ Produk andalannya (Kue Putu Piring) mempunyai keunikan khusus, yaitu menggunakan campuran tepung beras dan bawang putih di dalamnya.

$>$ Produk menggunakan bahan yang dijamin bersih, alami, berkualitas .

$>$ Cara penyajian produk sangat baik (produk baru dikukus saat setelah dipesan, sehingga terkesan fresh dan berkualitas).

$>$ Tekstur luarnya kue putu piring agak lembut jika masih panas namun tetap gurih karena ada campuran isi didalamnya gula aren dan albe (pewangi makanan berupa biji-biji seperti rempahrempahan).

b) Weakness :

Kemasan kurang praktis, serta kurang menunjang dan kurang sesuai dengan sifat produk, dapat dilihat dari uap panas yang tembus hingga membasahi kemasan (seperti berembun).

$>$ Belum adanya penggunaan identitas (terutama pada kemasan), misalnya tidak ada penggunaan merek. Hal ini menyebabkan orang menjadi ragu akan keaslian dan kualitas produk.

c) Opportunity :

$>$ Dapat lebih banyak dibeli sebagai oleholeh/ buah tangan.

Dapat memperluas jangkauan layanan pesan antar atau kerjsama dengan 
aplikasi Go-Food atau Gimi.

> Dapat memperluas pasar dengan membuka gerai-gerai baru dipusat Pariwisata Tanjung Setumu dan Kota Tanjungpinang.

d) Threat:

$>$ Ada kompetitor dengan jenis produk serupa dengan lokasi dan harga yang sama.

$>$ Adanya kompetitor dengan produk yang lebih beragam dengan inovasi varian rasa yang baru.

\section{HASIL DAN PEMBAHASAN}

Desain kemasan yang dirancang bertujuan untuk memperbaiki kemasan lama yang memiliki masalah pada ketahanan kemasan dan juga bertujuan merubah citra merek dan kemasan.Produk merupakan hasil tradisional khas kue melayu yang sepenuhnya menggunakan bahan-bahan yang berasal dari alam.Perancangan desain kemasan dan merek kue putu piring Bu Kay dilakukan setelah meninjau desain kemasan yang dinilai kurang memenuhi fungsi-fungsi kemasan seperti fungsi pengemasan, fungsi ekonomi, fungsi estetika dan fungsi distribusi.Tak hanya itu, dalam kemasan produk juga kurang memiliki fungsi komunikasi dan informasi yang memadahi, terlihat dari kemasan yang sederhana dan kurang menarik.

Berikut contoh kemasan yang selama ini digunakan oleh Bu Kay :

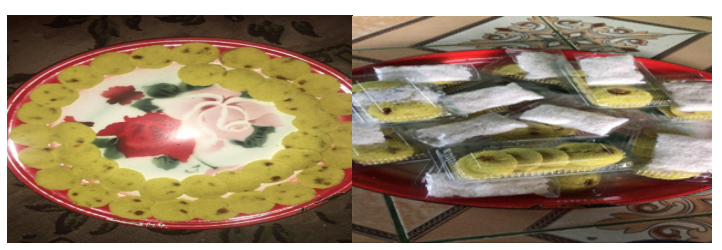

Gambar 2. Kemasan lama yang digunakan

$\mathrm{Bu}$ Kay masih menggunakan mika dan plastik pembungkus es

Brand Positioning yang ingin ditampilkan dalam kemasan baru produk Kue Putu Piring ini adalah sebuah kemasan yang higienis dan berkualitas. Produsen Bu Kay selalu menerapkan prinsip untuk menjaga agar produknya tetap higienis dan berkualitas, hal ini dilakukan mulai dari proses produksi yang selalu menggunakan bahan-bahan dasar yang berkualitas, selalu menjaga kebersihan selama proses produksi berlangsung hingga di lokasi penjualanpun pemilik Bu Kay selalu menerapkan prinsip higienis dan selalu melakukan kontrol terhadap anaknya yang membantu membuatnya, baik itu tata cara pembuatan hingga masuk kedalam dandang kukusan dan kebersihan tempat cetakan kue terjamin, dan lain-lainnya. Selama ini, brand positioning tersebut masih belum tampak dari kemasan lama Bu Kay.

Kemasan yang baik dan yang akan digunakan semaksimal mungkin dalam pasar harus mempertimbangkan dan dapat menampilkan beberapa faktor di antaranya seperti berikut ini:

\section{Faktor pengamanan}

Kemasan harus dapat melindungi produk terhadap berbagai kemungkinan yang dapat menjadi penyebab timbulnya kerusakan barang.

\section{Faktor ekonomi}

Perhitungan biaya produksi yang efektif.Termasuk pemilihan bahan sehingga biaya tidak melebihi proporsi manfaatnya.

\section{Faktor pendistribusian}

Kemasan harus mudah didistribusikan.Mulai dari pabrik ke distributor maupun pengecer sampai ke tangan konsumen.

\section{Faktor komunikasi}

Sebagai media komunikasi kemasan menerangkan dan mencerminkan produk, citra merek.Serta bagian dari produksi dengan pertimbangan mudah dilihat, dipahami dan diingat.

\section{Faktor ergonomi}

Pertimbangan agar kemasan mudah dibawa atau dipegang, dibuka dan mudah diambil.

\section{Faktor estetika}

Dengan tujuan mencapai mutu daya tarik visual secara optimal.

\section{Faktor identitas}

Kemasan harus berbeda dengan kemasan lain. Selain itu juga harus memiliki identitas produk agar mudah dikenali dan dibedakan dengan produk-produk yang lain.

\section{Faktor promosi}

Kemasan mempunyai peranan penting dalam bidang promosi.Dalam hal ini kemasan berperan sebagai silent sales person.

\section{Faktor lingkungan}

Dengan cara menggunakan kemasan- 
kemasan yang ramah lingkungan (environmentally friendly), dapat didaur ulang (recyclable) atau dapat dipakai ulang (reusable).

Sehubungan dengan permasalahan yang ada, akan dilakukan redesain dan inovasi kemasan kue putu piring Bu Kay, sehingga produk dengan cita rasa dan resep yang khas ini memiliki citra/ image yang baik, serta dapat dimaksimalkan fungsinya. Di samping itu, tetap menjamin keamanan dan kepraktisan mengkonsumsi produk yang ada didalamnya, serta cocok untuk dijadikan oleh-oleh.

Kemasan yang baru akan dirancang untuk mempermudah pendistribusian produk, memudahkan konsumsi produk di dalamnya dengan bentuk kemasan yang sederhana, penyediaan ruang dalam kemasan untuk mempermudah konsumsi produk di dalamnya beserta makanan pendampingnya, serta menyediakan kemasan yang dapat digunakan sebagai alas untuk memakan/ konsumsi produk di dalamnya. Oleh karena itu, dari segi identitas kemasan akan dirancang dengan visual yang lebih sesuai untuk menunjukkan positioning $\mathrm{Bu}$ Kay, yaitu higienis dan berkualitas. Selain itu akan dilakukan desain logo/merek untuk lebih menyesuaikan dengan image $\mathrm{Bu}$ Kay dan mendukung perancangan kemasan ini. Sesuai wawancara dengan produsen, menyetujui untuk dibuatkan desain merek dan kemasan yang baik untuk mendongkrak penjualan.

Kemudian untuk menjawab tujuantujuan kreatif yang telah disebutkan di atas, dirancang sebuah konsep strategi untuk perancangan kemasan baru produk kue putu piring Bu Kay, antara lain sebagai berikut:

\section{Konsep Perancangan}

Tujuan kreatif dari perancangan desain kemasan kue putu piring Bu Kay ini adalah menciptakan kemasan baru yang sesuai dengan sifat produk, praktis, dapat melindungi, cocok untuk oleh-oleh, menarik perhatian, serta memiliki identitas yang jelas sehingga Bu Kay dapat semakin dikenal oleh masyarakat. Selain itu, perancangan kemasan ini juga bertujuan untuk menampilkan citra/ image dari $\mathrm{Bu}$ Kay, yaitu produk Kue Tradisional yang higienis dan berkualitas.

\section{Pola dasar bentuk kemasan}

Pola dasar bentuk kemasan kue putu piring akan dirancang dengan bentuk yang praktis dan sesuai dengan karakteristik produknya. Pertimbangan pemilihan bentuk kemasan tersebut dilihat dari faktor ergonomi, estetik, kemudahan distribusi dan konsumsi, serta identitas. Ada beberapa kemasan yang akan dirancang pada perancangan kali ini. Kemasan primer dari produk yang dimiliki, yaitu kemasan satuan/ langsung makan, kemasan sekunder yang lebih diarahkan untuk mewadahi dan mempermudah pembawaan kemasan primer.Kemasan Tersier yakni kemasan yang diperlukan untuk menyimpan, pengiriman atau identifikasi.Keseluruhan pola dasar bentuk kemasan yang digunakan adalah bentuk geometris (persegi).Pola dasar persegi digunakan karena menjadi pola dasar yang paling mudah untuk dikembangkan. Kemasan sekunder sendiri terbagi menjadi tiga buah ukuran, yaitu kemasan sekunder untuk isi lima, sepuluh dan lima belas.

\section{Gaya desain}

Gaya desain yang digunakan dalam perancangan kemasan ini akan menyesuaikan dengan positioning dari $\mathrm{Bu}$ Kay, yaitu higienis dan berkualitas. Pendekatan yang dilakukan adalah dengan konsep gaya desain minimalis. Pada desain kemasan ini akan digunakan kombinasi elemen visual, yaitu vector illustration dari bahan-bahan utama pembuatan produk Bu Kay beserta produkproduknya yang disusun sedemikian rupa sehingga menciptakan pattern dengan susunan yang unik, visual minimalis, yang memiliki white space, dan tampak bersih, serta kemudian dikombinasikan dengan tipografi yang tetap menjaga dan mengutamakan simplisitas desain. Hal ini juga dimaksudkan untuk menimbulkan kesan higienis dan berkualitas.

\section{Sistem Buka Tutup}

Sistem buka tutup pada kemasan ini akan dibuat dengan sederhana untuk memudahkan konsumen dalam membuka/ menggunakan kemasan, serta saat menutupnya kembali. Untuk kemasan kelapa parutnya yang berada di dalam menggunakan plastik dengan sistem buka tutup pada bagian atasnya.

\section{Warna}

Pada perancangan kemasan ini, warnawarna utama yang akan digunakan dengan 
warna penuh putih diselimutin hijau dan kuning (pada logo) yang ada di kemasannya, Selain itu, penggunaan warna tersebut dalam psikologi warna diyakini dapat meningkatkan selera terhadap makanan dan membangkitkan nafsu. Warna putih dalam psikologi warna menggambarkan kebersihan makan, sehingga penggunaan warna putih juga dapat menggambarkan citra Bu Kay yaitu higienis dan berkualitas.

\section{Nama merek dan logo}

Dalam perancangan desain kemasan ini nama merek menggunakan nama $\mathrm{Bu}$ Kayati namun disingkat dengan "Bu Kay" agar tampak kekinian dari segi panggilannya. Kemudian, foto yang diambil dari nuansa Pulau Dompak yang ada bukit-bukitnya dan ilalang-ilalang serta rumah panggung ditambah lambang padi yang merupakan bahan dasar dari pembuatan kue putu piring.

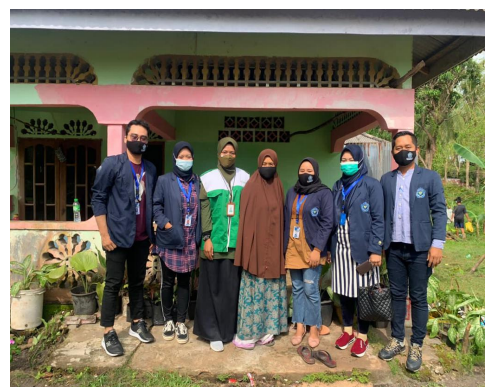

Gambar 3. Pengabdian Masyarakat bersama Yakesma dan Bu Kay

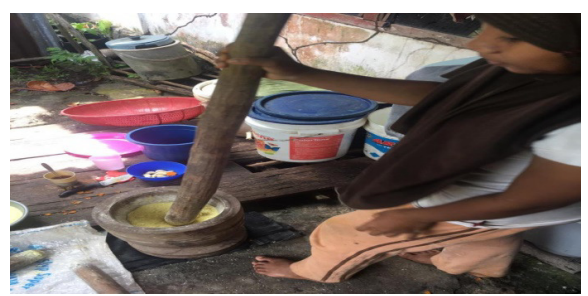

Gambar 4. Proses Pembuatan Kue Putu

Piring, penggilingan beras menggunakan alat

Tradisional (Lesung) dicampur rempah kunyit dan alba

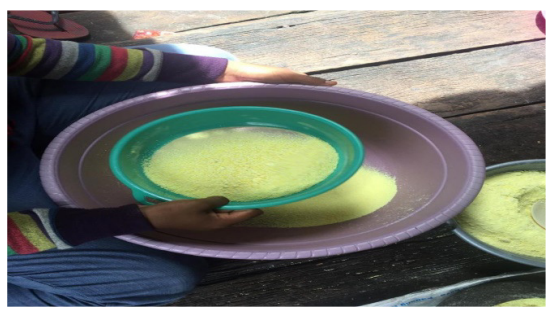

Gambar 5. Proses pengayakan beras menjadi tepung

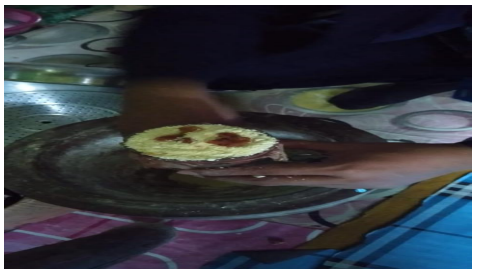

Gambar 6. Proses Pencetakan kue putu piring

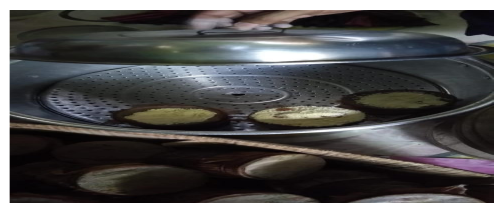

Gambar 7. Proses pengukusan kue putu piring

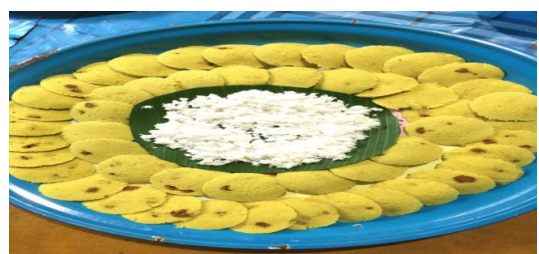

Gambar 8. Kue putu piring sudah siap di Packaging

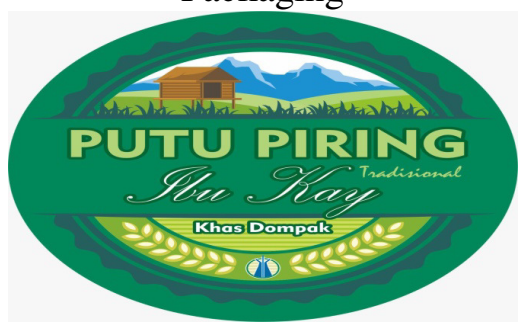

Gambar 9. Pembuatan Branding/Logo/merek Kue Putu Piring Bu Kay

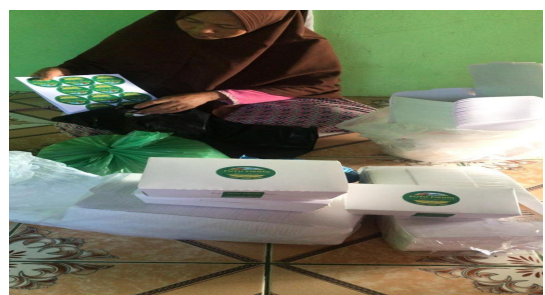

Gambar 10. Mengedukasi Bu Kay cara

Packaging dan meletakkan Branding padaKue Putu Piring

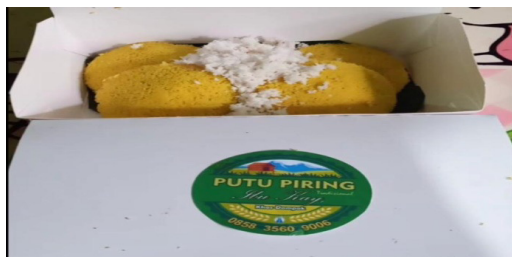

Gambar 11. Penyusunan Kue Putu Piring Bu Kay kemasan Sekunder isi 5 (lima) 


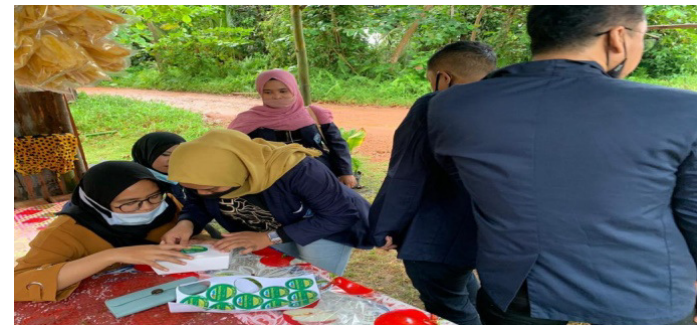

Gambar 12. Memberikan edukasi kembali cara meletakkan Branding dan Packaging kue putu piring serta cara pembukuan kas melalui anaknya Bu Kay

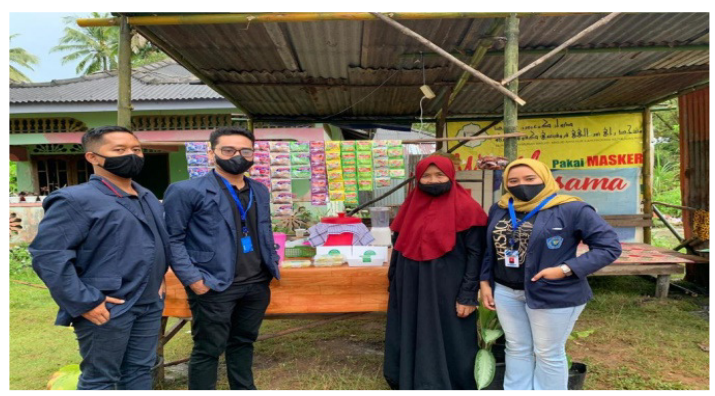

Gambar 13. Bersama mendirikan stand/tempat jualan didepan rumah Bu Kay yang lokasinya bertepatan dijalan besar menuju Pantai Tanjung Setumu - Kelurahan Dompak

\section{Hasil Pengujian}

Kemasan Setelah kemasan selesai dicetak, selanjutnya kemasan akan diuji untuk mengetahui kesesuaiannya dengan kriteria kemasan yang baik. Dalam perancangan ini bahan material yang digunakan pada kemasan adalah grease resistant paper dan kertas art paper yang dilaminasi bolak-balik.Lewat pelapisan kertas dengan material yang dapat menahan basah uap panas/minyak sekaligus aman untuk kontak langsung dengan makanan.

Berdasarkan uji coba yang dilakukan, setiap kemasan dapat berfungsi dengan cukup baik.uap yang keluar dari produk dapat tertahan di ruang kemasan saja dalam waktu yang lama, sehingga kemasan ini akan cocok untuk dijadikan oleh-oleh (flek minyak/ uap panas tidak tembus hingga sampai ke tempat tujuan oleh-oleh). Lalu untuk permasalahan konsumsi, kemasan ini memudahkan untuk konsumsi secara langsung, dikonsumsi di perjalanan ataupun untuk konsumsi saat dibawa pulang, makanan pendamping juga sudah lebih mudah untuk dikonsumsi bersama dengan produk ini. Selain itu, kemasan primer juga dapat menjadi alas makan yang dapat memudahkan konsumen memegang dan mengkonsumsi produk. Dari segi ergonomi, kemasan tersier ini sudah memiliki kemudahan bagi konsumen untuk menggunakannya secara praktis, baik untuk diambil isinya maupun untuk dibawa.Kemudian dari faktor visual dan identitas, kemasan sudah memiliki identitas yang jelas.Identitas yang dibuat dengan desain logo yang baik, juga sudah menyampaikan citra dan keaslian dari kue putu piring $\mathrm{Bu}$ Kay, sehingga kemasan juga sekaligus memenuhi faktor komunikasi dan promosi produk.

\section{KESIMPULAN}

Sebuah kemasan yang baik adalah kemasan yang dapat melindungi produk di dalamnya, sesuai dengan sifat produknya, dan merepresentasikan isi produk di dalamnya. Melalui proses perancangan ini, dapat diketahui bahwa kehadiran desain kemasan sangat penting keberadaannya bagi sebuah produk atau merek. Pada perancangan desain kemasan produk kue putu piring $\mathrm{Bu}$ Kay ini, kemasan dirancang agar dapat menjawab segala permasalahan yang ada.

Permasalahan tersebut diantaranya adalah dari segi distribusi (masalah uap panas ataupun isi dalam putu piring seperti gula aren yang meleleh ataupun minyak goreng yang tembus, hal ini terlebih jika produk dibeli dengan tujuan untuk oleh-oleh), segi konsumsi (wadah kurang memadai dan praktis untuk konsumsi langsung), dan segi identitas (material kemasan belum ada, keterangan yang tidak ada pada kemasan, dan identitas, seperti logonya tidak ada menggambarkan image, keaslian serta keunikan produk sehingga masih dapat ditiru oleh pesaingnya).

Dari permasalahan tersebut, perancangan ini berusaha memecahkan dari segi kemasan yang praktis dan cocok untuk oleh-oleh.Pada kemasan yang baru ini, kemasan dirancang agar praktis dan baik untuk dibawa maupun untuk mengkonsumsi produk di dalamnya, serta mengatasi permasalahan uap panas yang seringkali mengganggu kenyamanan saat hendak mengkonsumsi produk di dalamnya.

Dengan adanya kemasan primer yang tahan minyak atau uap panas, akan membantu memudahkan dalam memegang 
dan mengkonsumsi produk di dalamnya. Kemasan sekunder yang telah dilaminasi dapat menahan minyak/uap air hingga tidak tembus ke bagian luar kemasan, sehingga produk dapat didistribusikan dengan baik.Lalu dari segi ergonomi, dengan adanya kemasan besar dapat membantu memudahkan pembawaan produk.Kemudian dari faktor visual dan identitas, kemasan sudah memiliki identitas yang jelas (dengan penggunaan bahan material yang baik, dan tata letak, serta penggunaan logo yang seragam).Identitas yang dibuat dengan desain logo, juga diharapkan dapat menyampaikan image, positioning dan keaslian dari Kue putu piring $\mathrm{Bu}$ Kay sendiri, sehingga kemasan juga sekaligus memenuhi faktor komunikasi dan promosi produk.

\section{SARAN}

Dalam merancang desain kemasan, ada banyak hal yang harus dipertimbangkan, baik dari sisi estetis maupun fungsionalnya, termasuk bentuk kemasan, visual grafis, identitas, sisi ergonomi dan faktor-faktor lainnya.Pembuatan struktur desain kemasan bukanlah hal yang mudah dan cukup memakan waktu, sehingga observasi dan studi yang mendalam dan rinci mengenai kemasan, desain kemasan, serta sifat-sifat produk yang dirancang sangatlah penting demi merancang sebuah kemasan yang baik.Dalam perancangan desain kemasan, inovasi boleh dan sah-sah saja untuk digunakan.Namun banyak yang harus dipertimbangkan untuk itu semua, jadi membutuhkan pemikiran yang matang agar produk tersebut dapat dikenal dan diterima oleh masyarakat luas terutama di Kota Tanjungpinang.

\section{UCAPAN TERIMA KASIH}

Kami mengucapkanterima kasih kepada Panitia Pusat Penelitian dan Pengabdian Masyarakat(P3M) Sekolah Tinggi Ilmu Ekonomi(STIE) Pembangunan Tanjungpinang dan Yayasan Kesejahteran Madani (Yakesma) Provinsi Kepulauan Riau karena telah membiayai dan mendukung kegiatan ini. Kami tak lupa juga mengucapkan terima kasih tak terhingga kepada Bapak Satriadi, S.AP., M.SC sebagai Dosen Pendamping Lapangan yang telah memberikan ilmu dan pengalamannya serta terima kasih kami juga untuk Ibu Kayati sebagai owner "Kue Putu Piring Bu Kay"karena telah bersedia menjadi mitra dan menjalin kerja sama yang baik.

\section{REFERENSI}

[1] Bangsa, P. G., Christianna, A., Studi, P., Komunikasi, D., Seni, F., Petra, U. K., \& Siwalankerto, J. (2018). Perancangan Brand Identity Produk Perawatan Kulit Wajah L'Neviz Cosmetics. 1-9.

[2] Budiman, D. F., Yuwono, E. C., \& Yusuf, V. (2019). Perancangan Desain Kemasan Produk TOKO Kue Kering "DEWI" Semarang.

[3] Evan Tandio, Ahmad Adib, A. W. (2013). Dhisti Cookies Sebagai Camilan Di Kota Solo. Cenadi 94.

[4] Kotler, P., \& Keller, kevin lane. (2011). Manajemen Pemasaran edisi 13 jilid 2 (A. Maulana \& yayat sri Haryati (eds.); 13 jilid 2). Erlangga.

[5] MK Bajuri. (2015). Pengaru Merek Dan Desain Kemasan Deodorant Rexona Terhadap Keputusan Pembelian DI Air Tawar Barat Kota Padang. Phys. Rev. E, 1993, 24.

http://ridum.umanizales.edu.co:8080/jspui/bit stream/6789/377/4/Muñoz_Zapata_Adri ana_Patricia_Artículo_2011.pdf

[6] Tunky, H., \& Kohardinata, C. (2016). Perancangan Desain Kemasan Pada Merk Keripik Pisang Bananation di Surabaya. Jurnal Manajemen Dan StartUp Bisnis, 1(1), 567-583.

[7] Viencencia, B., K, A. P., Sutanto, R. P., \& Siwalankerto, J. (2013). Perancangan Kemasan Kue Millecrepes “ Buttercream Cakery " di Bali Abstrak Pendahuluan.

[8] Wirawan, I. C., Natadjaja, L., Febriani, R., \& Siwalankerto, J. (2019). Perancangan Branding Dan Packaging. 